\title{
The "plus" side of epilepsy phenotyping
}

Sameer M. Zuberi, MD

Pasquale Striano, MD

Correspondence to Dr. Zuberi:

sameer.zuberi@nhs.net

Neurology ${ }^{\circledR} 2017 ; 89: 1-2$

See page 1210
The first clinical description of generalized epilepsy with febrile seizures plus (GEFS+) by Scheffer and Berkovic $^{1}$ in their landmark Brain article of 1997 represented a major step forward in the understanding of the genetic basis of the epilepsies. Coming 2 years after their identification, with collaborators, of the genetic basis for a relatively homogenous syndrome, autosomal dominant nocturnal frontal lobe epilepsy, the detailed phenotypic description of a single large Australian family with heterogeneous febrile seizure plus epilepsy phenotypes and a clear dominant pattern of inheritance put a novel perspective on genotype-phenotype relationships in the epilepsies. ${ }^{2}$ Shortly after, the SCN1A and SCN1B genes were linked to the syndrome, and subsequently the last 2 decades has confirmed that the majority of epilepsy genes show phenotypic heterogeneity and the majority of syndromes reveal genetic heterogeneity. ${ }^{3}$ Why one individual in a GEFS + family has a severe developmental and epileptic encephalopathy such as Dravet syndrome and another has simple self-limited febrile seizures is unknown, but is likely to be determined by other genetic factors influencing the $S C N 1 A$, or other major genes identified in a family.

Twenty years later, the Melbourne group has revisited GEFS + and further refined the classification and boundaries of this relatively common familial epilepsy syndrome. In this issue of Neurology ${ }^{\circledR}$, Zhang et al. ${ }^{4}$ analyzed the phenotypic spectrum in over 400 affected individuals in 60 (31 previously unreported) families. Clinical information was obtained from parents, spouses, or other eyewitnesses using a validated seizure questionnaire. Previous medical records were reviewed, including EEG, video-EEG monitoring, and MRI studies. Blood samples and genetic analysis was performed in the probands and family members where possible. Then the authors performed detailed electroclinical phenotyping on available affected families and compared their phenotypic and genetic data to those published in the literature over the last 19 years. By doing so, they have expanded the GEFS + spectrum and identified new phenotypes, namely focal seizures without preceding febrile seizures and classic genetic generalized epilepsies. As about $9 \%$ of affected individuals have focal epilepsies, the authors suggest that GEFS + be renamed genetic epilepsy with febrile seizures plus. This change in terminology is already widely accepted following several articles reporting focal seizures and epilepsies in GEFS + families. ${ }^{5,6}$ In addition, the phenotypic overlap between GEFS+ and the classic generalized epilepsies is considerably greater than previously reported. The authors coin the term earlyonset genetic generalized epilepsies for a small subset of patients. Whether this term has clinical and research utility will require further validation.

In their study, the authors report genetic variants in 11/31 GEFS + families. SCN1A was reported in 3 families and the relevance of some of the other variants, notably $S C N 9 A$, in terms of pathogenicity in GEFS + remains debatable. The report of SCN8A and PRRT2 is worthy of scrutiny. The PRRT2 variants segregate with self-limited infantile seizures in this family and are not seen with other phenotypes. The SCN8A variant segregates within a family to a child with a severe $S C N 8 A$ developmental and epileptic encephalopathy and to a mosaic father.

The 2017 International League Against Epilepsy Classification of Seizure Types and the Epilepsies reflects scientific advances over the last 3 decades by incorporating an etiologic classification alongside the electroclinical phenotype. ${ }^{7,8}$ This approach focuses the clinician on stratifying treatment when possible based on etiology. Well-described epilepsy syndromes, such as Ohtahara and Lennox-Gastaut syndromes, which had established electroclinical phenotypes, are now regarded as of diminished clinical utility unless they are also classified by their structural or genetic etiology. Zhang et al. present a large house for GEFS + and it is likely that to define prognosis for the individual and aid genetic counseling, detailed genetic classification will be needed alongside precision phenotyping; at present, this is only possible for a minority of GEFS + cases. This article is an important addition to the literature, providing clarification on several details of the phenotypic spectrum and

From the Paediatric Neurosciences Research Group (S.M.Z.), Royal Hospital for Children \& University of Glasgow, UK; and Pediatric Neurology and Muscular Diseases Unit, Department of Neurosciences, Rehabilitation, Ophthalmology, Genetics, Maternal and Child Health (P.S.), University of Genoa, "G. Gaslini” Institute, Italy.

Go to Neurology.org for full disclosures. Funding information and disclosures deemed relevant by the authors, if any, are provided at the end of the editorial. 
raising more questions about the role and relevance of genetic heterogeneity.

\section{STUDY FUNDING}

No targeted funding reported.

\section{DISCLOSURE}

S.M. Zuberi receives research funding from Epilepsy Research UK, Dravet Syndrome UK, Glasgow Children's Hospital Charity, and UCB Pharma. He has attended advisory boards and received speaker's honoraria paid to his institution's charitable fund from Zogenix, GW Pharma, and Biocodex. P. Striano received honoraria from FB Health, Kolfarma srl, and Eisai Inc., and research support from the Italian Ministry of Health. Go to Neurology.org for full disclosures.

\section{REFERENCES}

1. Scheffer IE, Berkovic SF. Generalized epilepsy with febrile seizures plus: a genetic disorder with heterogeneous clinical phenotypes. Brain 1997;120:479-490.

2. A missense mutation in the neuronal nicotinic acetylcholine receptor alpha 4 subunit is associated with autosomal dominant nocturnal frontal lobe epilepsy. Nat Genet 1995;11:201-203.

3. Orsini A, Zara F, Striano P. Recent advances in epilepsy genetics. Neurosci Lett 2017;S0304-3940:30402-0.

4. Zhang Y-H, Burgess R, Malone JP, et al. Genetic epilepsy with febrile seizures plus: refining the spectrum. Neurology 2017;89:1210-1219.

5. Abou-Khalil B, Ge Q, Desai R, et al. Partial and generalized epilepsy with febrile seizures plus and a novel SCN1A mutation. Neurology 2001;57:2265-2272.

6. Scheffer IE, Harkin LA, Grinton BE, et al. Temporal lobe epilepsy and GEFS+ phenotypes associated with SCN1B mutations. Brain 2007;130:100-109.

7. Scheffer IE, Berkovic S, Capovilla G, et al. ILAE classification of the epilepsies: position paper of the ILAE Commission for Classification and Terminology. Epilepsia 2017;58: 512-521.

8. Fisher RS, Cross JH, French JA, et al. Operational classification of seizure types by the International League Against Epilepsy: position paper of the ILAE Commission for Classification and Terminology. Epilepsia 2017;58:522-530. 


\title{
Neurology
}

\author{
The "plus" side of epilepsy phenotyping \\ Sameer M. Zuberi and Pasquale Striano \\ Neurology published online August 25, 2017 \\ DOI 10.1212/WNL.0000000000004399
}

This information is current as of August 25, 2017

\section{Updated Information \&} Services

Subspecialty Collections

\section{Permissions \& Licensing}

Reprints including high resolution figures, can be found at: http://www.neurology.org/content/early/2017/08/24/WNL.0000000000 004399.full.html

This article, along with others on similar topics, appears in the following collection(s):

All Clinical Neurology

http://www.neurology.org//cgi/collection/all_clinical_neurology All Epilepsy/Seizures

http://www.neurology.org//cgi/collection/all_epilepsy_seizures

Generalized seizures

http://www.neurology.org//cgi/collection/generalized_seizures

Partial seizures

http://www.neurology.org//cgi/collection/partial_seizures

Information about reproducing this article in parts (figures,tables) or in its entirety can be found online at:

http://www.neurology.org/misc/about.xhtml\#permissions

Information about ordering reprints can be found online: http://www.neurology.org/misc/addir.xhtml\#reprintsus

Neurology ${ }^{\circledR}$ is the official journal of the American Academy of Neurology. Published continuously since 1951, it is now a weekly with 48 issues per year. Copyright @ 2017 American Academy of Neurology. All rights reserved. Print ISSN: 0028-3878. Online ISSN: 1526-632X.

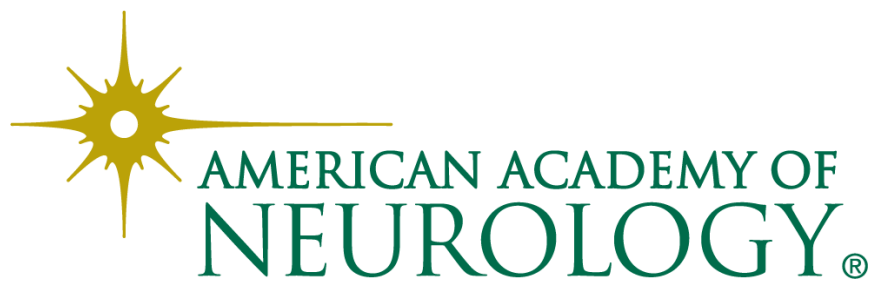

